\title{
The Merchant of Venice: The Allegorical Equation of Art and Commodity
}

\author{
Fatemeh (Sara) Pakdamanshahri \\ PhD Candidate, Yeditepe University, Istanbul Turkey
}

\begin{abstract}
John Cage narrates: “...Somebody said that Brecht wanted everybody to think alike. I want everybody to think alike... Everybody looks alike and acts alike, and we're getting more and more that way. I think everybody should be machine. I think everybody should be alike." The interviewer asks Cage: "Isn't that like pop art?" And consequently, Cage responds: "Yes, that's what pop art is, liking things." 1 Shakespeare's plays have long been put under scrutiny, praised, and devalued through various theoretical lenses. Regardless of the innumerable doctrines against which his tragedies and comedies have been over-analyzed, tending to his art in terms of the essence of his works, the artistry of them seems more than crucial. Morality, ethics and individual and collective philosophical readings of Shakespearean plays have coexisted with and mirrored in words, hence literature. There seems to be no way out but to weigh Shakespearean plays against these impossibly heavy concepts. This paper intends to undergo an ethical reading of The Merchant of Venice, through the ideas of Emmanuel Kant and Jeremy Bentham. Consequent to the ethical reading of The Merchant of Venice, the artistic value(s) of it will be discussed, whether one is blessed with an artistic sense or otherwise is a question to be tended to.
\end{abstract}

Key words: Emmanuel Kant, Ethics, Jeremy Bentham, Kitsch, pseudo-art, The Merchant of Venice, William Shakespeare

\section{INTRODUCTION}

The Merchant of Venice has been among those controversial plays having a hard time falling under the right category. The questioning of its genre is perhaps the matter of another paper, however, considering the play to be a comedy and thus not attending to it seems to be far from academic understanding. Some critics have taken the play seriously enough to have actually been conveying a message, including Harold Bloom: "I know of no legitimate way in which the Merchant of Venice ought to be regarded as other than an anti-Semitic text..."2 Whereas, some have considered it nothing but a comedy, devoid of any specific connotation. Burton Raffel considers the play merely a sort of pop art, not intending to mean anything plausible:

We must be particularly careful not to lean on a tremendously effective and enormously popular comic drama, trying to place it in an ideological schema-like that which we have come to call anti-Semitism- in which it has little if any legitimate place. $^{3}$

Yet, nowhere in the history of literary criticism, have we been authorized to decide what literary text is to be regarded worthy of analysis and what is not. When it comes to

\footnotetext{
1 Daniel Tiffany, My Silver Planet: A Secret History and Poetry and Kitsch, edited by Douglas Mao, (Baltimore: John Hopkins University Press, 2014, 206-207.

2 Harold Bloom, "An Essay by Harold Bloom", in The Merchant of Venice Fully Annotated, with an Introduction, by Burton Raffel, William Shakespeare. (New Haven and London: Yale University Press, 2006), 151.

${ }^{3}$ Burton Raffel, "Introduction", in The Merchant of Venice Fully Annotated, with an Introduction, by Burton Raffel, William Shakespeare. (New Haven and London: Yale University Press, 2006), xix.
} 
Shakespeare, he seems more than canonical enough for us to make a pause and consider his works credible to contemplate upon.

Ethics and ethical order have been walking hand in hand with literature since the very beginning of the primal literary productions. Their existence and crucial role in the determination of art and pseudo-art -considering literature among the classification of arts- is hard to deny. In this study Kantian categorical imperative ${ }^{4}$ and Bentham's utilitarianism ${ }^{5}$ will be touched upon in order for the relationships of the characters of the play to be analyzed.

Consequent to the texturizing the ethical relationships governing of the world of the play and through a brief analysis of the reception theory back in the seventeenth century, the paper discusses kitsch -pseudo-art- and its specifics in literature to help taking an offspring step in placing this offspring of Shakespeare in the literary canon in both Elizabethan and modern times.

\section{Kant and Categorical Imperative Moral Reasoning}

In his Groundwork of the Metaphysics of Morals, Kant has gone through details about the necessity and categorical nature of moral conduct, specified to a great extent. Here, however, we are in dire need to focus our attention to the two main maxims of his categorical imperative moral reasoning.

Before specifying what he meant by categorical imperative, let us also note that he has distinguished between hypothetical moral reasoning and categorical moral reasoning. So he clarifies: "Now, if the action would be good merely as a means to something else the imperative is hypothetical; if the action is represented as in itself good hence as necessary in a will in itself conforming to reason, as its principal, then it is categorical." 6,7 . What he has intended for us to notice is the distinction between, what is categorically right and what is known to be hypothetically desirable. To benefit from the consequences or offspring of a certain action, one resolves to take necessary actions only and only for the sake of achieving something other than the doing of the action itself. On the other hand, categorical imperative necessitates doing of a sort of action regardless of the results and consequences it brings us. One wills to act under the maxims of categorical imperative solely because it is in itself moral and conforms to reason. He further clarifies:

... one imperative that, without being based upon and having as its condition any other purpose to be attained by certain conduct, commands this conduct immediately. This imperative is categorical. It has to do not with the matter of action and what is to result from it, but with the form and principle from which the action itself follow; and the essentially good in the action consists in the disposition, let the result be what it may. This imperative may be called the imperative of morality. ${ }^{8,9}$

One has no way out of a universal dilemma that suggests itself in response to this overgeneralized statement of Kant's. If the key to morality as he puts it is to act only for the

\footnotetext{
${ }^{4}$ Immanuel Kant, Groundwork of the metaphysics of Morals. Trans. And ed. by Mary Gregor. (Cambridge: Cambridge University Press, 1997)

5 Jeremy Bentham, An Introduction to the Principles of Morals and Legislation. (New York: Dover Publications Inc., 2007)

${ }^{6}$ Kant, Groundwork of the metaphysics of Morals, 25.

7 Publisher's italics

8 Ibid, 27.

9 Publisher's bold
} 
sake of the essentially good in the action, how is one to undoubtedly choose the supposedly good from the inevitable bad? He further clarifies in this regard:

There is, therefore, only a single categorical imperative and it is this:

Act only in accordance with that maxim through which you can at the same time will that it become a universal law. ${ }^{10}$

Not only does this clarify the essentially good in itself, but also puts such a huge responsibility on each and every human being's shoulders as an agent. Further on, in the discussion of human beings as moral beings and the necessity of categorical imperative moral reasoning, Kant suggests the inevitable necessity of the definition of another imperative, the practical imperative. By that he intends every moral human being:

So act that you use humanity, whether in your own person or in the person of any other, always at the same time as an end, never merely as a means. ${ }^{11}$

Should we be to take away the gist of Kantian absolute morality, the universal essence of good needs to be present in each and every action of ours and in practicality, we are to treat every human being including ourselves as ends and not means. What the practicality maxim does in the practical sense is a call to action for placing and practicing a distinction between objects and subjects. Human beings are to be seen, defined, and treated as subjects, autonomous and valued/devalued regardless of their functions to achieve other than themselves.

\section{The Absence of Categorical Imperative Moral Reasoning in The Merchant of Venice}

Shylock's code of conduct which has been recognized by all the dramatic personae including her very own daughter to be overly materialistic is linked with him being a Jew. He is criticized and insulted innumerable times by the Christian community. However, the overt Christian hypocrisy is hard to ignore. There exists literally no character in the play that does not valuate and appreciate earthly possessions.

The play begins with an utmost need of fortune on the part of a Christian, a dear friend to Antonio, who the play is named after. Bassanio is to ask for a fair lady's hand, that is Portia. In Bassanio's words she is left with a huge sum of inheritance:

Bassanio In Belmont is a lady richly left

And she is fair, and fairer than the word,

Of wondrous virtues. ${ }^{12}$

(I. I. 160-162)

Since the lady is considerably wealthy, Bassanio needs to borrow a considerable amount to match her earthly worth. And let us not neglect the order in which Bassanio describes Portia. It comes in a three-staged description, no doubt first comes the fortune, then the beauty and only at the final stage the virtues that she possesses are spoken of. It is worth paying attention since in the course of the play the Christian community never misses an opportunity to condemn Shylock for being materialistic and valuing nothing but his fortune. Apparently a mere virtuous personality does not suffice when it comes to matrimonial bonds. Bassanio has to leave for Belmont with an undeniable amount of 3000 ducats to be let in Portia's household.

Bassanio, thus turns to Shylock, the Jew money lender, abhorred by nearly every Christian in Venice, from time to time addressed as a "dog" without a slight possibility of shame:

10 Ibid., 31.

11 Ibid., 38.

12 William Shakespeare, The Merchant of Venice. (New Haven and London: Yale University Press, 2006) 
Antonio I am as like to call thee $\mathrm{so}^{13}$ again,

To spit on thee again, to spurn thee too.

(I. III. 123-124)

In fact, it is Shylock who tells of the innumerable times that he has been insulted in various ways, and yet he is approached once needed. He has recognized the Christian mannerism towards himself and in confronting them about it. Shylock calls for a justification on the part of Antonio, a sort of response that not only does admit to him having been treated as a mere object/means to achieve an end, but also does hope that there might be a slight explanation for it.

Shylock Fair sir, you spat on me on Wednesday last,

You spurned me such a day, another time

You called me dog and for these courtesies

I'll lend you thus much monies?

(I. III. 119-122)

Alas, neither Bassanio nor Antonio have a sound reason to propose for their vulgar attitude towards Shylock. Shakespeare has artfully provided as many pieces of information to justify this hostile attitude towards Shylock, when he provides as many seemingly (merely appealing to the Christian society back at the $17^{\text {th }} \mathrm{C}$.) plausible reasons for Shylock's lack of morality:

Shylock I hate him for he is a Christian.

But more, for that in low simplicity

He lends out money gratis, and brings down

The rate of usance here with us in Venice.

If I can catch him once upon the hip,

I will feed fat the ancient grudge I bear him.

He hates our sacred nation, and he rails

Even there where merchants most do congregate

On me, my bargains, and my well-won thrift,

Which he calls "interest". Cursed be my tribe

If I forgive him.

(I. III. 36-46)

At this point, any manifestation of hatred against Shylock must be justified. He hates Antonio because he is a Christian, he feeds on interest he charges on the money he lends, and he has sworn never to forgive Antonio. The image of a blood-sucking Jew who holds grudges against people just because they do not belong to his tribe is adequately drawn. However, does the author ever appeal for the reason a human being is so foul-hearted? Does he call for the audience's pity towards dark-spirited a man such as Shylock?

One needs to keep in mind the historical and cultural background of the production of the play. In the early $17^{\text {th }}$ century, the common behavioral trend among the majority Christian society has been hatred and contempt towards Jews without any exception. As James Shapiro who has done a thorough study of the matter states: "... the Jew as irredeemable alien and the Jew as a bogeyman... co-existed at deep linguistic and psychological levels." ${ }^{14}$ Shakespeare has undoubtedly written The Merchant of Venice with all its biases against Shylock to appeal to the

13 This line of Antonio comes after Shylock reminds him that he was called "a dog" by Antonio several times, and Antonio is anaphorically referring to that. (I. III. 119-122)

14 James Shapiro, Shakespeare and the Jews (New York: Columbia University Press, 1996), 24. 
audience and not to awaken their conscience. Thus, any irrational vulgarism against the Jew is not only acceptable, but a stage prop to excite and incite the audience.

Nowhere in the play Antonio holds himself responsible to respond to what Shylock accused him of. He does not feel obliged to justify his using attitude towards Shylock, as it is considered an obvious and fair code of conduct, to hate and objectify a Jew. John Gross in Shylock: A Legend and Its Legacy, goes in detail to shed light upon the sinister image of the moneylenders in Elizabethan era: "Shakespeare's alien Shylock cannot really be understood independent of the larger social tensions generated by aliens and their economic practices in London in the mid1590s... most moneylenders in Elizabethan literature were thoroughly sadistic."15

To assume that Shylock asks for a pound of flesh on the condition that the 3000 ducats borrowed would not be returned in three months, is merely an act of sadism and foulheartedness seems like a simplistic approach to reading of drama unless one considers one more time the audience for whom the play has been staged.

"By the end of the sixteenth century,... Jews were increasingly identified not with usury per se, but with outrageous and exploitative lending for profit."16

Shylock is no doubt wounded by the constant temerity he gets from the Christian majority. His servant -Gobbo- leaves him for another Christian to serve. His very own daughter believes she lives in hell and resolves to marry a Christian to be saved. Otherwise, he would ask for nothing but the profit on top of the money he intended to lend. A greedy Jew, who prioritizes wealth over else wishes for the death of a Christian in return. Whether it is not the sake of injustice and foul remarks he receives or due to another reason is left unworthy of being tended to. However, it is evidenced in the play itself that Shylock wishes Antonio to be dead solely for he has been unjustly wronged several times by him, reduced to a villain devoid of any humanly emotions. This happens after he hears his daughter has left him:

Shylock ... he hath disgraced me, and hindered

Me half a million, laughed at my losses, mocked at my gains,

Scorned my nation, thwarted my bargains, cooled my friends,

Heated mine enemies, and what's the reason? I am a Jew. Hath

Not a Jew eyes? Hath not a Jew hands, organs, dimensions,

Senses, affections, passions, fed with the same food, hurt with

The same weapons, subject to the same diseases, healed by the

Same means, warmed and cooled by the same winter and

Summer as a Christian is? If you prick us, do we not bleed? If

You tickle us, do we not laugh? If you poison us, do we not

Die? And if you wrong us, shall we not revenge? If we are

Like you in the rest, we will resemble you in that. If a Jew

Wrong a Christian, what is his humility? Revenge! If a

Christian wrong a Jew, what should his sufferance be, by

Christian example? Why, revenge!

(III. I. 46-60)

Although Shakespeare has intended Shylock to seem absolutely ruthless in the dream of his revenge over all the wrong he has been the target of, he sounds extremely logical. Shylock seems to know the measure for measure rule, and let us not neglect the fact that what triggers him to come out this strong and pour his heart out at the audience -both in and outside the

15 John Gross, Shylock: A Legend and Its Legacy (New York: Simon and Schuster, 1992), 50.

${ }^{16}$ Shapiro, Shakespeare and he Jews, 99. 
play- is the news about the loss of his daughter, his own flesh and blood. Once more, I would have to emphasize that although some critics as mentioned previously believe that this play, being classified as a comedy must not be taken as an example of antisemitism, the few opportunities that the Jew is given to express himself proves otherwise. One needs to be aware of the fact that Shylock is not given a voice to express honestly the turmoil he has had to go through, but to express his ruthlessness and lack of capacity to forgive, which is ironically a characteristic expected from the Jew and merely the Jew.

Moreover, where does the responsibility of the Christian party of the agreement reside in? After all, Shylock and Antonio both agree on the terms of the 3000 ducats against a pound of flesh. How can it be that Antonio is never questioned on his mannerism and senses once he agrees to the losing of his flesh in case he does not return the borrowed sum in the threemonth agreed time? He is only too confident that he will return the debt:

Antonio Come on, in this there can be no dismay,

My ships come home a month before the day. (I. III. 174-5)

Another rather too poignant instance of Shylock's being mistreated and denied of being capable of having humanly emotions is when he finds out that his only daughter has left him without a proper farewell. He is accused of worrying over the fortune that Jessica has perhaps taken with her:

Shylock My own flesh and blood to rebel!

(III. I. 30)

He is undoubtedly wounded emotionally that this time one of the very few people he trusted and loved betrayed him as well. However the response he gets from the Christians, defines how he should feel:

Salarino There is more difference between thy flesh and hers,

Than between jet and ivory, more between your bloods than

There is between red wine and Rhenish (III. I. 33-5)

In case there is a slight uneasiness left in his heart the reason must be something else as Jessica is not his blood and flesh.

Bassanio holds Shylock responsible for Antonio's death. As is portrayed in this brief dialogue, Shylock finally finds a voice of his own; this time genuinely, however left in vain. Shakespeare cunningly gives Shylock a tiny line worthy of pondering upon, it is left unattended eventually. No one is ever held responsible for justifying their self-righteous hatred against Shylock. It is a supposedly intended dialogue that rather turns into a soliloquy, however on the part of the speaker it was intended to be a dialogue. Since it gets no response neither in a verbal nor in a physical sense of the word, it turns into a compulsory aside, to which the Elizabethan audience has no response either.

Bassanio Do all men kill the things they do not love?

Shylock Hates any man the thing he would not kill?

(IV. I. 66-7)

Bassanio, the good friend of Antonio is pleading for Antonio's life by trying to appeal to Shylock's emotions and conscience.

Bassanio This is no answer, thou unfeeling man

To excuse the current of thy cruelty! (IV. I. 63-4)

It seems only plausible if the community has made a judgement about the evil in Shylock's soul to stick with it. Shylock's voice evaporates as there is no ethical audience to it. He yearns for 
the Christians to look inside at their hypocrisy; that although they do not lay their hands on the Jew's throat, they never cease hating him either. They would rather keep him alive as there might come one or two other opportunities whereby he is needed, to be used as another means for another achievement.

Shylock is to take away a pound of flesh of Antonio's, as sealed in the deal:

Portia And you must cut this flesh from off his breast.

The law allows it and the court awards it. (IV. I. 299-300)

However, when he loses to the literalization game of Portia:

Portia Tarry a little, there is something else.

This bond doth give thee here no jot of blood,

The words expressly are a pound of flesh.

(IV. I. 302-3)

To shylock and to any other citizen of Venice, including Antonio, it has been obvious that flesh is not to be taken away unless the victim's blood sheds. And more blatant than this, has been the death of Antonio that has been at stake from the very beginning of the play, otherwise no pleading for his life and no attempt to appeal to shylock's conscience would have come of any place.

The penalty intended for him accords with his left-alone dialogue above: Hates any man the thing he would not kill? (Iv. I. 67).

Shylock is to lose his fortune:

Portia Then take thy bond, take thou thy pound of flesh,

But in the cutting it, if thou dost shed

One drop of Christian blood, thy lands and goods

Are by the laws of Venice confiscate

Unto the state of Venice.

And forcefully convert to Christianity, since his daughter is married to a Christian:

Antonio He presently become a Christian, (IV. I. 384)

He is in an existential dilemma now, it is either death (the confiscation of his fortune to the benefit of the state of Venice as mentioned above) or the change of identity. Shylock has no choice but to choose one. As John Gross puts the matter, "Nothing can alter the fact that, seen through the eyes of the other characters, Shylock is a deeply threatening figure, and that the threat he poses is of a peculiarly primitive kind." 17 The Christian society has to rid him of his identity now that his state stays in his hands until the moment of death. The Jew has to merge into one of the accepted Venetians, otherwise he will not be tolerated.

\section{JEREMY BENTHAM AND UTILITARIANISM}

One of the philosophies that places itself almost against Kant's categorical imperative is Jeremy Bentham and John Stuart Mill's utilitarianism. Utilitarianism's mission is to bring the greatest good to the greatest number of the living in a given society, even in case it entails doing something categorically immoral. Let us note that in An Introduction to the Principles of Morals

17 Gross, Shylock: A Legend and Its Legacy, 29. 
and Legislation, Bentham goes in detail to describe the "interest of individual" 18 and the "interest of the community"19.

He bases his whole argument through assuming natural the idea that human being's actions are governed by two major principles of pain and pleasure. Thus, he believes that the consciousness human beings form is where one is to discover morality: "Nature has placed mankind under the governance of two sovereign masters, pain and pleasure. It is for them alone to point out what we ought to do, as well as to determine what we shall do."20

Bentham appears to justify the necessity of determination of our actions by pain and pleasure principle based on the idea that they are the fruit of human nature, and thus, unarguably legitimate to be recognized.

He then, goes on to determine a principle called "the principle of utility" 21 which he defines as: "By the principle of utility is meant that principle which approves or disapproves of every action whatsoever." 22 According to Bentham, the principle of utility tells us what is to be done and what is to be avoided.

Bentham clarifies the whole concept of utilitarianism: "By utility is meant that property in any object, whereby it tends to produce benefit, advantage, pleasure, good, or happiness to prevent the happening of mischief, pain, evil, or unhappiness, to the party whose interest is considered..."23

It is of crucial importance to note that combining the concepts of "the principle of utility" and "utility" according to Bentham, leaves us with nothing but to conclude that one is to act based on the maxims which are to bring about happiness and rid us of pain. Some critics including Robert Shackleton, have had doubts about the right interpretation of what Bentham actually meant by the greatest good for the greatest number. Shackleton states that it has been an act of mistranslation and a possible confusion. Shackleton says that in 1768 Bentham has been in a state of confusion and drawing conclusion between the two works he was engaged in reading by Beccaria and Joseph Priestly. ${ }^{24}$ However, in A Fragment on Government, Bentham explicitly repeats himself: "It is the greatest happiness of the greatest number that is the measure of right and wrong." 25

\section{Manifestation of Utilitarianism in The Merchant of Venice}

According to the maxim of the greatest happiness for the greatest number, the Christian community in Venice has made certain to act utilitarian in various situations. Let us not neglect the fact that to provide the utmost possible happiness for the largest number requires the annihilation of morality in the sense that Kant has defined. It is on us not to consider what the Jew deserves, and how he should be treated, rather to guarantee the Christians' joy. Shylock is condemned of being greedy and charging interest on the loans he gives people, as it is amongst

\footnotetext{
18 Jeremy Bentham, An Introduction to the Principles of Morals and Legislation, 19.

19 Ibid, 20.

20 Ibid, 16.

21 Ibid, 16.

22 Ibid, 17.

23 Ibid, 18.

${ }^{24}$ Robert Shackleton, “The Greatest Happiness of the Greatest Number: The History of Bentham's Phras”', Studies on Voltaire and The Eighteenth Century (Oxford: The Voltaire Foundation, 1972), 90.

${ }^{25}$ Jeremy Bentham, A Comment on the Commentaries and a Fragment on government, in The Collected Works of Jeremy Bentham, edited by J. H. Burns and H. L. A. Hart (London: Oxford University Press, 1997), 393.
} 
the seven deadly sins. And yet his state is to be confiscated in favor of the state to bring benefit to the largest community:

Portia ... thy lands and goods

Are by the laws of Venice confiscate

Unto the state of Venice.

Shylock does attempt to remind the greatest number of his autonomy and personhood:

Shylock Shall I not have barely my principal?

(IV. I. 339)

And he is explicitly denied that right:

Portia Thou shalt have nothing but the forfeiture,

To be taken so as thy peril, Jew.

(IV. I. 340-1)

And thus as long as he is a minority, he is a peril to the happiness of the majority.

A very heartbreaking tailoring of morality and immorality, good and evil happens when Portia is awaiting the right suitor to decipher the deceased father's messages on the chests. And thereby, wed Portia. Portia's father has intended three chests with labels, all conveying messages to be functioning as judges of the characters of Portia's suitors. Here Morocco -the first suitor to express his lack of morality reads:

Morocco The first of gold, who this inscription bears:

"Who chooseth me, shall gain what men desire."

The second, silver, which this promise carries:

"Who chooseth me, shall get as much as he deserves."

This third, dull lead, with warning all as blunt:

"Who chooseth me must give and hazard all he hath."

(II. VII. 4-9)

Obviously, Morcoco fails, and then comes another who attempts the silver chest and henceforth it is Bassanio, who does not betray the humanity intended at the heart of Christianity. He aims for the lead-holding chest, as he has prepared himself to hazard all he has for the pure love of Portia. However, just like Shylock's questioning of the Christian's morality, the query of Portia's great fortune and Bassanio's mentioning of it once describing Portia for the first time, remains abandoned. The simplistic parade of Christian's lack of greet for earthly possessions does no doubt function in the structure of The Merchant of Venice. Bassanio needed a considerable amount to even set foot on the path of asking Portia's hand. Jessica had to steal from the father to marry the Christian. The Duke and the state of Venice are more than willing to confiscate Shylock's belongings, and yet this humanly trait is only abhorred once practiced by the outsider, the Jew.

We have discussed the various aspects of categorical imperative and utilitarianism. Their respective absence and presence in the characterization of The Merchant of Venice, i.e. the choices made based on believing in the latter rather than the former, the play is a rather consistent manifestation of the principle of utility.

\section{KITSCH}

Consequent to the discussion of the play's portrayal of utilitarianism, I would like to discuss how all this relates to the concept of kitsch. There exists no inclusive definition of kitsch with which the artistic community, including critics, feels content. However, we could delve into a number common and widely-acceptable interpretations of the concept of kitsch. 
According to Calinescu: "The word "kitsch" was first used in the nineteenth century to refer to inexpensive pictures sold as souvenirs to tourists." ${ }^{26} \mathrm{He}$ further on clarifies that kitsch has arisen from the need to multiply art and artistic objects, to please and to give the consumer of art that can be multiplied: "Kitsch held a profound power to please, to satisfy, the easiest and the most widespread popular aesthetic nostalgia." 27

Thus, what this sort of art lacks is being unique and original. And what it certainly conveys is feeling and impression that its consumers are worthy of being exposed to and understanding nice and fancy rather than mundane and every-day. This category entails the objects that one's livelihood does not depend on, yet are picturesque to the eyes and the souls of the ones not fortunate enough to be exposed to the real scenery or the real art, as one may put it.

Kundera's interpretation of kitsch is not only worthy of attention, but extremely illuminating since he broadens the borders of kitsch and its application to everyday life experiences: "Kitsch causes two tears to flow in quick succession. The first tear says: How nice to see children running on the grass! The second tear says: how nice to be moved together with all mankind, by children running on the grass! It is the second tear that makes the kitsch kitsch. The brotherhood of man on earth will be possible only on a base of kitsch."28 To Kundera, one can have a genuine, pure, honest experience at a moment of exposition to a phenomenon, be it the running and playing of children in this case, however, one loses the sense and purpose of the experience by wanting to evaluate the experience and granting themselves a sort of appreciation of having been able to experience such a thing as mentioned. What he means by "the brotherhood of man on earth" is the greediness, the desire to multiply, to produce copies of a simple genuine experience that must have been felt in a fraction of a second and let go of. To attempt to grade or degrade an aesthetic or emotional experience, to judge and evaluate an experience that has something to do with art is in need of creating value systems that have nothing to do with art and with honesty but a great deal to do with a commercialized and commodified variations of art, which is kitsch.

The oversimplified definition of Greenberg: "Kitsch pretends to demand nothing of its customers, except their money." 29 has painted a rather comprehensive picture of for whom kitsch is intended. To perceive kitsch fully, the audience is in need of nothing but some time and money to waste to be pleased, to be entertained. The reason Greenberg has opted for the verb "pretend" on the part of kitsch, in my humble opinion is that the story does seem to be a simple story of entertainment on the surface, however, once it happens it does more than that. The consequences of exposing oneself to kitsch for the sake of enjoyment in exchange for a rather inconsiderable amount of money are far greater than the audience imagines. It dulls the senses through a pleasant process of pleasing so artfully, than one never suspects anything immoral to have happened. Thus, I would like to conclude that Greenberg has artistically and wittily portrayed the pretention aspect of kitsch in his clarification of the matter.

Let us synthesize Kundera's example and Greenberg's clarification. A clear distinction needs to be pointed out between the two tears he mentions. The first tear which the rightful one is the

\footnotetext{
${ }^{26}$ Matei Calinescu, Five Faces of modernity: Modernism, Avant-garde, Decadence, Kitsch, Postmodernism (North Carolina: Duke University Press, 1987), 234.

27 Ibid, 230.

28 Milan Kundera, The Unbearable Lightness of Being, translated by Michael Henry Heim (London: Faber and Faber, 2015), 251.

${ }^{9}$ Clement Greenberg, “Avant-Garde and Kitsch" in Clement Greenberg: The Collected Essays and Criticism. Vol. I, Perceptions and Judgements, 1939-1944, Edited by John O’Brian (Chicago: Chicago University Press, 1986 ), 12.
} 
result of being exposed to an earthly phenomenon which we call art for a while, however, the second one is out of the joy of being entertained, which is the ultimate purpose behind kitsch. To entertain the masses, the uneducated, the ones who would rather be tingled than to shaken, the ones who desire the 'pleasant' and not 'the truth'.

Another critic who has contributed to the clarification of the border between art and kitsch, Hermann Broch says: "The essence of kitsch is the confusion of the ethical category with the aesthetic category; a 'beautiful' work, not a 'good' one is the aim: the important thing is an effect of beauty." 30

According to Hermann Broch, once one is on the verge of exposing themselves to the 'beautiful' and not the 'good', the former the aesthetic (although not the genuine aestheticism, but the commercialized) and the latter the ethical, the desired and yearned for is "kitsch" rather than "art". He provides us with further explanation: "The Kitsch system requires its followers to 'work beautifully', while the art system issues the ethical order: 'work well'. Kitsch is the element of evil in the value system of art."31

\section{The Merchant of Venice as Kitsch}

Having touched a few inches below the surface of pop art, let us now tend to put under scrutiny how The Merchant of Venice is a great manifestation of kitsch. Shakespeare has depicted the plot from a previously successful (successful in the sense of popularity) fictional work to guarantee the positive publicity and the wide range of acceptance of his play among its spectators.

As Burton Raffel states: "As is so often the case with Shakespeare, many elements of the story are borrowed in this case principally from Il Pecorone ("The Blockhead", a collection of stories published in Florence in 1558." ${ }^{2}$, the success of the play, that is, the popularity is thus guaranteed based on the well-reception of the original -Il Pecorone-.

One no doubt needs to consider the socio-economical as well as the political context in which the play was written. As for The Merchant of Venice, as Burton Raffel states, the play was first publish in 1600. The advertising of the play apparently had had no purpose but to entice the potential readers. What the printer-publisher thought was most worthy of public attention. The cover of the play reads: "The most excellent history of the Merchant of Venice, with the extreme cruelty of Shylock the Jew towards the said merchant, in cutting a just pound of his flesh, and the obtaining of Portia by the choice of three chests." 33 Thus it is clear that mass conversion of Jews into Christianity happening in 1570s and 80s has prepared the audience's mentality and thus their well reception of The Merchant of Venice.

As mentioned before in the discussion of categorical imperative and utilitarianism in The Merchant of Venice, the characters -Christians- do not spare Shylock his life and livelihood, until he converts to Christianity against his will. We delved into the plot in detail to observe that Shylock has been reduced to a dog, a mere means of Christians' achievement and happiness. He is never given the freedom to be who he is and live his livelihood, without being

\footnotetext{
${ }^{30}$ Hermann Broch, "Notes on the Problem of Kitsch" in Kitsch, An Anthology of Bad Taste, compiled and edited by Gillo Dorfles, translated by Gabriele Mazzotta, (London: Studio Vista Limited, 1969), 71.

31 Ibid, 63.

32 Burton Raffel, "Introduction, xviii.

33 Ibid, xvii.
} 
given the look of contempt. Shylock is a mere stage prop, to whom all the arrows of hatred are pointed.

Shylock's lack of voice and autonomy even as an antagonistic character in the structure of the play, takes away the chances of the protagonists of the play to fully develop and have something worthy to say. Shakespeare has done his best to swim in accordance with the flow. James Shapiro explains that "the word Jew had entered into the English vocabulary in the thirteenth century as a catchall term of abuse."34. He also clarifies that the existence and practice of stock epithets such as "I hate thee as I do a Jew,' 'I would not have done so to a Jew,' and "None but a Jew would have done so"'35 were the guarantee of nothing but the fact that back in Elizabethan time "the Jew as irredeemable alien and the Jew as bogeyman ... co-existed at deep linguistic and psychological levels." 36

The juxtaposition of appraisal and devaluating of wealth, money lending, and money being confiscated as punishment, the disguise-deception games, low level literary game played by Portia, on top of Shylock's immature antagonistic figure have all led to the malfunction of the principles of the fictional world in The Merchant of Venice.

The absence of any sort of thought provoking ideas, the lack of demand for further contemplation on the part of the audience, hence lack of authenticity, the parading of safe, sound and absolutely immoral codes of conduct in the play have left us with nothing but an absolute sample of kitsch, which demands nothing from the audience, but their money. The sort of pop art that pleases, with components arranged to function beautifully rather than ethically.

The whole Christian community Shakespeare has created in the play and the values that parade themselves in the face of the spectators are all widely appealing to them, which again guarantees that his play is extremely entertaining to the intended audience. The ethical principle does not work in the world of Antonio and Shylock, it is merely the pleasure principle and the pretty principle at work. There is no real antagonist.

The elements of immorality, namely deception and disguise have been so playfully and beautifully woven into the plot that they never provoke the audience's conscience, as if as long as there is a happy ending for the majority, disguise and deception are not only allowed, but legitimate, since they please us. The elements of disguise and deception never ask the spectator to question the element of morality. As long as the end, which is popularity and acceptance is achieved, the means is justified.

\section{CONCLUSION}

To conclude, I would like us to have a look at Eco's perception of kitsch, which again sheds light on not only the artistic element itself, but the audience which plays a crucial part in the existence or non-existence of art itself.

"Kitsch is consumed by people who are too uneducated and too busy to decode the complex information stored in the fine art and yet desiring something akin to a fine art experience, instead consume kitsch which has borrowed fine art stylemes but which offers these in an unintegrated fashion and for immediate consumption." ${ }^{37}$

\footnotetext{
34 James Shapiro, Shakespeare and the Jews, 24.

35 Ibid, 24.

36 Ibid, 24.

37 Umberto Eco, "The Structure on Bad Taste" in The Open Work, translated by Anna Cancogni (Cambridge, Massachusetts: Harvard University Press, 1989), 69-70.
} 
Literature, according to Rosenblatt, exists not on the printed pages, but the performed version on the stage or the perceived words and concepts by the readers that eventually become part of the consciousness of the perceiver. Charles Bressler paraphrases what Rosenblatt states in Literature As Exploration:

"The true poem can exist only in the reader's consciousness, not on the printed page.

When a reader and text transact, the poem and therefore, meaning are created; they exist only in the consciousness of the reader." 38

Shakespeare has created an unequal, unfair world -in terms of accordance with reality- with no autonomous antagonist to contribute to the creation of a legitimate protagonist. His first and foremost goal has been to set a strong foot in the intended audience's consciousness with zero possibility of rejection. Shakespeare as Brecht has put it and was previously mentioned in the abstract, has succeeded to make his audience "like things".He has played a crucial role in the normalization of bad taste. Our playwright has been more than triumphant in disguising kitsch to be sold as art, to accompany the audience only six centuries later.

As long as the play is ethically -in the sense of Kantian ethics- flawed, as long as the antagonistic characters are given no voices to truly manifest themselves, as long as its purpose is to entertain and not to awaken the audience, what we are dealing with is kitsch and definitely not art, as Robert C. Solomon says in On Kitsch and Sentimentality, in bad art which is a result of bad taste, "there is unimaginative imitation and straightforward plagiarism, the manipulation of emotion." 39

The Merchant of Venice works against the morality principle, authenticity, and feeds on popularity and bad taste and plagiarism. Not only has he fed on bad taste, but contributes to its fluidity, legitimization and naturalization. The Merchant of Venice seems to match the parameters of a successful byproduct of deception, of disguise. Leo Steinberg poses a gleaming light upon our confusion: "The artist does not simply make a thing, an artifact... what he creates is a provocation." 40 What is it that has been provoked since the unceasing parade of the Venetians has started entertaining us in the $17^{\text {th }}$ century? Have we been equipped to "bypass reflection in Zijderveld's words?

"In his study of cliché, Anton Zijderveld points to the cliché's "capacity to bypass reflection"that is, to its iceberg-like formation, in which the greater part of its meaning lies submerged." 41

\section{BIBLIOGRAPHY}

Bentham, Jeremy. A Comment on the Commentaries and a Fragment on government, in The Collected Works of Jeremy Bentham, edited. by J. H. Burns and H. L. A. Hart, London: Oxford University Press, 1997.

Bentham, Jeremy. An Introduction to the Principles of Morals and Legislation.. New York: Dover Publications Inc., 2007

Bloom, Harold. "An Essay by Harold Bloom”, in The Merchant of Venice Fully Annotated, with an Introduction, by Burton Raffel. New Haven and London: Yale University Press, 2006.

\footnotetext{
${ }^{38}$ Charles E. Bressler, Literary Criticism: An Introduction to Theory and Practice (New Jersey: Pearson Prentice Hall, 2007), 84.

${ }^{39}$ Robert C. Solomon, On Kitsch and Sentimentality in The Journal of Aesthetics and Art Criticism. Vol. 49, No. 1, (The United States of America: The American Society for Aesthetics, Winter 1991), pp 1-14, 3.

40 Daniel Tiffany, My Silver Planet: A Secret History and Poetry and Kitsch, 214.

41 Ibid, 214.
} 
Pakdamanshahri, F. S. (2020). The Merchant of Venice: The Allegorical Equation of Art and Commodity. Advances in Social Sciences Research Journal, 7(1) 178-191.

Bressler, Charles E. Literary Criticism: An Introduction to Theory and Practice New Jersey: Pearson Prentice Hall, 2007.

Broch, Hermann. "Notes on the Problem of Kitsch" in Kitsch, An Anthology of Bad Taste, translated by Gabriele Mazzotta, compiled and edited by Gillo Dorfles,. London: Studio Vista Limited, 1969.

Calinescu, Matei. Five Faces of modernity: Modernism, Avant-garde, Decadence, Kitsch, Postmodernism. North Carolina: Duke University Press, 1987.

Eco, Umberto. "The Structure on Bad Taste" in The Open Work, translated by Anna Cancogni Cambridge, Massachusetts: Harvard University Press, 1989.

Greenberg, Clement. "Avant-Garde and Kitsch" in Clement Greenberg: The Collected Essays and Criticism. Volume I, Perceptions and Judgements, 1939-1944, edited by. John O'Brian. Chicago: Chicago University Press, 1986.

Gross, John. Shylock: A Legend and Its Legacy. New York: Simon and Schuster, 1992.

Kant, Immanuel. Groundwork of the metaphysics of Morals. Translated and edited by Mary Gregor.. Cambridge: Cambridge University Press, 1997.

Kundera, Milan. The Unbearable Lightness of Being, translated by Michael Henry Heim. London: Faber and Faber, 2015.

Raffel, Burton. "Introduction", in The Merchant of Venice. Fully Annotated, with an Introduction, by Burton Raffel. New Haven and London: Yale University Press, 2006), xix.

Shackleton, Robert. “The Greatest Happiness of the Greatest Number: The History of Bentham's Phrase” in Studies on Voltaire and The Eighteenth Century. Oxford: The Voltaire Foundation, 1972

Shakespeare, William .The Merchant of Venice. Fully Annotated, with an Introduction, by Burton Raffel. New Haven and London: Yale University Press, 2006.

Shapiro, James. Shakespeare and The Jews. New York: Columbia University Press, 1996.

Solomon, Robert C. On Kitsch and Sentimentality in The Journal of Aesthetics and Art Criticism. Volume 49, No. 1. The United States of America: The American Society for Aesthetics, Winter 1991.

Tiffany, Daniel. My Silver Planet: A Secret History and Poetry and Kitsch, edited by Douglas Mao. Baltimore: John Hopkins University Press, 2014. 